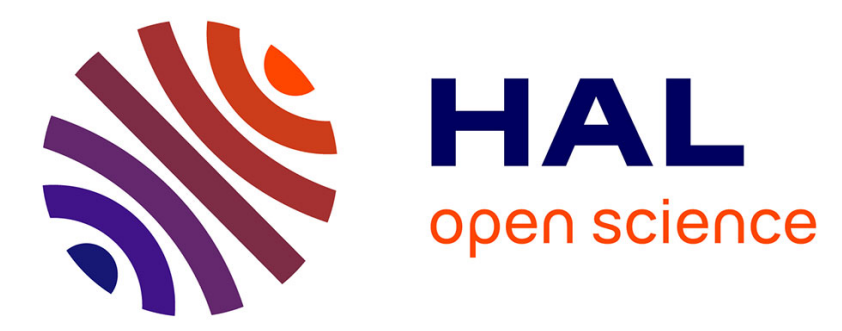

\title{
XAFS Study on the Local Structure of Mo in Molten Nitrates
}

\author{
N. Matsubayashi, C. Geantet, P. Afanasiev, Y. Soldo, J. Hazemann
}

\section{To cite this version:}

N. Matsubayashi, C. Geantet, P. Afanasiev, Y. Soldo, J. Hazemann. XAFS Study on the Local Structure of Mo in Molten Nitrates. Journal de Physique IV Proceedings, 1997, 7 (C2), pp.C2-1179C2-1180. 10.1051/jp4:19972182 . jpa-00255251

\section{HAL Id: jpa-00255251 https://hal.science/jpa-00255251}

Submitted on 1 Jan 1997

HAL is a multi-disciplinary open access archive for the deposit and dissemination of scientific research documents, whether they are published or not. The documents may come from teaching and research institutions in France or abroad, or from public or private research centers.
L'archive ouverte pluridisciplinaire HAL, est destinée au dépôt et à la diffusion de documents scientifiques de niveau recherche, publiés ou non, émanant des établissements d'enseignement et de recherche français ou étrangers, des laboratoires publics ou privés. 


\title{
XAFS Study on the Local Structure of Mo in Molten Nitrates
}

\author{
N. Matsubayashi*****, C. Geantet*, P. Afanasiev*, Y. Soldo** and J.L. Hazemann******* \\ * Institut de Recherches sur la Catalyse, 2 avenue Albert Einstein, 69626 Villeurbanne cedex, France \\ ** Laboratoire de Cristallographie, 25 avenue des Martyrs, BP. 166, 38042 Grenoble cedex 09, France \\ *** National Institute of Materials and Chemical Research, 1-1, Higashi, Tsukuba, Ibaraki 305, Japan \\ **** LGIT CNRS, UJF, BP. 53X, 38041 Grenoble, France
}

\begin{abstract}
The local structure of Mo compounds in the intermediate states of the synthesis in molten nitrates media has been studied by the XAFS method. The XAFS results showed that the local structure around Mo changes from distorted octahedral form of $\mathrm{MoO}_{3}$ to tetragonal form of $\mathrm{MoO}_{4}{ }^{2-}$ via an intermediate phase during the reaction. It has been shown that the intermediate species of Mo oxide exist as a mixture of polymolybdate such as $\mathrm{Mo}_{7} \mathrm{O}_{24}{ }^{6-}$ and $\mathrm{Mo}_{4} \mathrm{O}_{13}{ }^{2-}$.
\end{abstract}

\section{INTRODUCTION}

Molten nitrates provide an original chemistry and offer new opportunities for the preparation and synthesis of materials[1]. Reaction of $\mathrm{MoO}_{3}$ in molten nitrates was studied previously[2]. $\mathrm{MoO}_{3}$ dissolves in the bath and finally $\mathrm{MoO}_{4}{ }^{2-}$ monomers are stabilized but intermediate species are known to be formed. However, the mechanism of stabilization of oxoanions remains unknown. For this purpose, we have studied samples of Mo precursors in nitrate melts quenched at different temperatures by EXAFS.

\section{EXPERIMENTAL CONDITIONS}

Samples have been prepared from $\mathrm{MoO}_{3}$ precursor in a 10-fold molar excess of molten nitrates $\left(50 \mathrm{wt} \% \mathrm{KNO}_{3}\right.$ and $50 \mathrm{wt} \%$ $\mathrm{NaNO}_{3}$ mixture). The mixture was pre-heated at $150^{\circ} \mathrm{C}$ for $2 \mathrm{~h}$ under a flow of dry nitrogen to remove water and then the temperature was raised and quenched at various temperatures from 300 to $550^{\circ} \mathrm{C}$.

EXAFS measurements at Mo K-edge (20keV) have been performed at room temperature at the ESRF on CRG-IF beamline using a $\mathrm{Si}\left(\begin{array}{lll}3 & 1 & 1\end{array}\right)$ double crystals monochromator. The ESRF ring was operated with a current of $130-90 \mathrm{~mA}$ of $1 / 3$-fill mode at the electron acceleration of $6 \mathrm{GeV}$. The intensity of the incident $x$-ray (Io) and transmitted $x$-ray (I) were measured by monitoring of scattering $x$-ray from a Kapton film (thickness: $125 \mu \mathrm{m}$ for Io, $250 \mu \mathrm{m}$ for I) using silicon photodiodes. $\mathrm{MoO}_{3}$, $\mathrm{Na}_{2} \mathrm{MoO}_{4} .2 \mathrm{H}_{2} \mathrm{O}, \quad\left(\mathrm{NH}_{4}\right)_{6} \mathrm{Mo}_{7} \mathrm{O}_{24} .4 \mathrm{H}_{2} \mathrm{O}$ were measured as references.

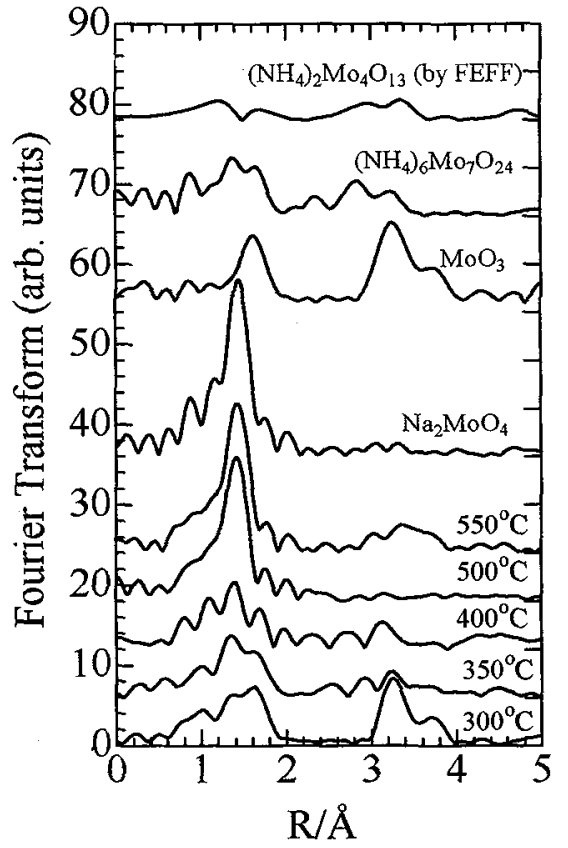

Fig.l Fourier transforms of Mo K-edge EXAFS for samples obtained from Mo precursors by quenching at various temperatures.

\section{RESULTS and DISCUSSIONS}

Figure 1 shows Fourier transforms of $\mathrm{k}^{3} \mathrm{X}(\mathrm{k})$ of Mo K-edge for samples quenched at various temperatures. The range of $\mathrm{k}=3$ to $17 \AA^{-1}$ were transformed with a Hamming window function at $10 \%$ of the part of the data on both sides. The distance $R$ is shorter by about $0.3 \AA$ than real distance due to the phase shift in scattering of electron. Peaks at 3.2 and $3.7 \AA$ in the Fourier transform at $300{ }^{\circ} \mathrm{C}$ which are similar to those of $\mathrm{MoO}_{3}$ indicate that the $\mathrm{MoO}_{3}$ precursor still remains and the intensity of 


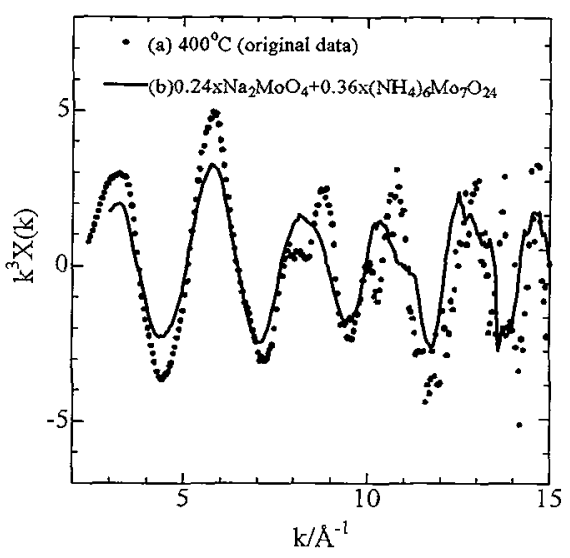

Fig.2. Fitting of EXAFS data in k-space using reference data.

the peaks decrease with increasing temperature. A large peak of $1.4 \AA$ which appears at 500 and $550^{\circ} \mathrm{C}$ is corresponding to a high symmetry of tetragonal in $\mathrm{MoO}_{4}{ }^{2-}$. These results show that $\mathrm{MoO}_{3}$ precursor transforms into $\mathrm{MoO}_{4}{ }^{2-}$ in progressing reaction. The Fourier transforms at 350 and $400{ }^{\circ} \mathrm{C}$ resemble to the spectra of $\left(\mathrm{NH}_{4}\right)_{6} \mathrm{Mo}_{7} \mathrm{O}_{24} .4 \mathrm{H}_{2} \mathrm{O}$.

To discuss quantitatively the $X(k)$ data of these samples were decomposed to those of references by fitting in the range of $k=3$ to $15 \AA^{-1}$ as shown in Fig. 2 . The fitting was performed under non-negative constraints for components. The Fourier transforms of residual $X(k)$ after subtraction of contribution from references were compared to those of simulation $X(\mathrm{k})$ for various $\mathrm{Mo}$ oxides by $\mathrm{FEFF}[3] . \quad \mathrm{Mo}_{4} \mathrm{O}_{13}{ }^{2-}$ were found to be one of the intermediate species. Adding simulation $\mathrm{X}(\mathrm{k})$ of $\mathrm{Mo}_{4} \mathrm{O}_{13}{ }^{2-}$ the fitting was carried out again.

Figure 3 shows composition of Mo species in the samples quenched at various temperatures obtained from EXAFS data by fitting using experimental data of reference samples and simulated data of $\mathrm{Mo}_{4} \mathrm{O}_{13}{ }^{2-}$ by FEFF. The concentration of $\mathrm{MoO}_{3}$ species decreases with increasing temperature and vanishes at $400{ }^{\circ} \mathrm{C}$. Presence of intermediate oxides such as $\mathrm{Mo}_{7} \mathrm{O}_{24}{ }^{6-}$ and $\mathrm{Mo}_{4} \mathrm{O}_{13}{ }^{2-}$ is maximum at $350^{\circ} \mathrm{C}$ and are transformed to $\mathrm{MoO}_{4}{ }^{2-}$ with increasing temperature. $\mathrm{MoO}_{4}{ }^{2-}$ is the dominant species at 500 and $550^{\circ} \mathrm{C}$. However, at 550 ${ }^{\circ} \mathrm{C}$ the presence of other species than the references can be emphasized.

Figure 4 shows Fourier transform of residual $\mathbf{k}^{3} \mathrm{X}(\mathrm{k})$ after subtraction of the fitting result for Mo K-edge EXAFS of the sample at $550{ }^{\circ} \mathrm{C}$. Figure 4 corresponds to Fourier transform for the other Mo species than the references used. The peak of $3.6 \AA$ at $550{ }^{\circ} \mathrm{C}$ is relatively long as usual Mo-Mo in Mo oxides. It suggests that another Mo species may be formed at $550^{\circ} \mathrm{C}$.

\section{References}

[1] Afanasiev P., Geantet C., Materials Chemistry and Physics, 41 (1995) 18

[2] Habboush D. A. and Kerridge D. H., Thermochim. Acta, 10 (1974) 187.

[3] Rehr J. J., Mustre de Leon J., Zabinsky S. I., Albers R. C., J. Am. Chem. Soc., 113 (1991) 5135.
Fig. 3 Composition of Mo species in samples obtained from Mo precursors using reference data.

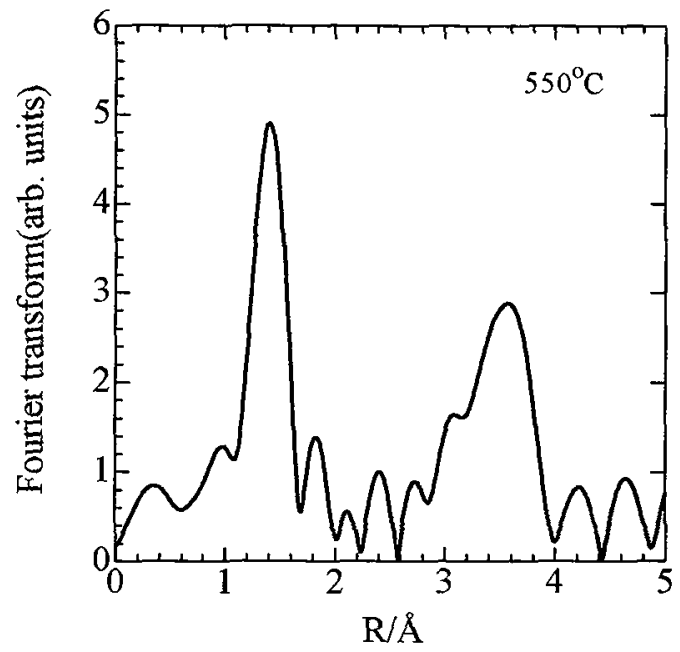

Fig. 4 Fourier transform of residual $\mathrm{k}^{3} \mathrm{X}(\mathrm{k})$ after subtraction of the fitting result for Mo K-edge EXAFS of the sample at $550^{\circ} \mathrm{C}$. by quenching at various temperatures obtained from EXAFS data by fitting 